Force to an armed conflict has been defined. The principle of humanity in treatment of prisoners of war, namely to avoid the discrimination based on race, skin color, religion or belief, gender, origin or property status or any other similar criteria has been disclosed.

The subjects entitled to prisoner of war status have been defined. Legal aspects of POW rights have been considered. International standards in treatment of this category of persons, namely hygiene and medical aid, discipline, use of the labor and wage, money, communication with the outside world, relations between them and authorities, the imposition of criminal and discipline sanctions, the release and direct repatriation after the cessation of hostilities have been accentuated. The need to strengthen penalties for violations of POW rights has been indicated.

Key words: armed conflict, hybrid war, combatant, non-combatant, a civilian, casualties of war, a prisoner of war, a civilian hostage, Anti-Terrorist Operation (ATO), Joint Forces Operation (JFO).

УДК 343.375 (477)

Крайник Г. С. кандидат юридичних наук, асистент кафедри кримінального права №1 Національного юоридичного університету імені Ярослава Мудрого (м. Харків, Україна)

Заточна В.О.

студентка 3 курсу Інституту прокуратури та кримінальної юстиції Національного юридичного університету імені Ярослава Мудрого (м. Харків, Україна)

\title{
ПРОБЛЕМНІ ПИТАННЯ КРИМІНАЛЬНОЇ ВІДПОВІДАЛЬНОСТІ ЗА ЛЕГАЛІЗАЦІЮ (ВІДМИВАННЯ) ДОХОДІВ, ОДЕРЖАНИХ У ЗЛОЧИННИЙ СПОСІБ
}

У статті висвітлено об'єктивну сторону складу злочину, передбаченого ч. 1 ст. 209 Кримінального кодексу України, а також п. 1 примітки до ст. 209 Кримінального кодексу. Розглянуто законодавче регулювання протидії легалізації доходів, одержаних у злочинний спосіб, запропоновано внести зміни до законодавства України в цій сфері. Приділено увагу невідповідності п. 1 примітки ст. 209 Кримінального кодексу України Конвенщії Ради Свропи про відмивання, пошук, арешт та конфіскацію доходів, одержаних у злочинний спосіб, та про фінансування тероризму. Запропоновано внести зміни до п. 1 ст. 209 Кримінального кодексу. Також розглянуто таку ознаку суб'єктивної сторони цього злочину, як мета. 3'ясовано, що це факультативна ознака суб'єктивної сторони, незважаючи на пояснення Пленуму Верховного Суду України.

Ключові слова: доходи, одержані в злочинний спосіб, легалізація (відмивання) доходів, протидія відмиванню доходів, предикатний злочин, фінансування тероризму.

Постановка проблеми. Економічне зростання сучасного суспільства нерозривно пов'язане із запобіганням різноманітним загрозам, що набувають особливого поширення в період реформування економічної системи. Проблема легалізації злочинних доходів перетворилася за останні (с) Крайник Г.С., 
декілька десятків років у міжнародну. Найсприятливішими для відмивання грошей $є$ нові фінансові ринки в країнах із перехідною економікою. Для України проблема легалізації доходів, одержаних у злочинний спосіб, стоїть наріжним каменем та потребує негайного вирішення, оскільки 3 кожним роком усе більша частина вітчизняного капіталу виводиться за кордон. До того ж актуальність дослідження обумовлюється різким збільшенням кількості злочинів, пов' язаних з відмиванням таких коштів, та проблемами, 3 якими зіткнулися правоохоронні органи при кваліфікації цих злочинів. Водночас проблемними питаннями кримінальної відповідальності за ст. 209 Кримінального кодексу України після ратифікації Конвенції Ради Свропи про конфіскацію доходів, одержаних у злочинний спосіб, та про фінансування тероризму й набрання нею чинності 01 червня 2011 року є: 1) визначення предикатного злочину; 2) питання мети цього злочину.

Аналіз останніх досліджень і публікацій. Проблему легалізації доходів, одержаних у злочинний спосіб, досліджують багато вчених, зокрема: П. П. Андрушко, О. М. Бандурка, В. І. Борисов, М. В. Бондарєва, О. О. Дудоров, В. А. Журавель, М. В. Корнієнко, Ю. В. Коротков, В. В. Лавров, Н. М. Мироненко, В. О. Навроцький, В. М. Попович, Б. Г. Розовський, О. О. Чаричанський.

Скажімо, О. М. Бандурка під відмиванням доходів, одержаних у злочинний спосіб, розуміє приховування істинного джерела отриманих матеріальних цінностей, перетворення незаконної готівки в іншу форму активу, приховування істинного власника незаконно набутих доходів тощо [1, с. 35].

Науковці зазначають, що відмивання грошей - це завершальний етап перетворення злочинності у високодохідне та ефективне виробництво, під час якого відбувається протиправна та шкідлива для суспільства концентрація економічної, а відтак і політичної влади в руках неконтрольованої групи осіб [3, с. 8].

В. А. Журавель визначає спосіб легалізації злочинних доходів як систему дій, прийомів, операцій, що спрямована на підготовку до легалізації та приховання, маскування іiі наслідків, а також безпосереднє введення злочинним доходів у легальний сектор [2, с. 323].

Формування цілей. Метою статті є визначення проблемних питань кримінальної відповідальності за легалізацію (відмивання) доходів, одержаних у злочинний спосіб. Проаналізовано діяння, які можуть бути предикатними щодо цього злочину та їх відповідність Конвенції Ради Європи про відмивання, пошук, арешт та конфіскацію доходів, одержаних у злочинний спосіб, та про фінансування тероризму. Також приділено увагу такій ознаці суб'єктивної сторони цього злочину, як мета. Крім цього в статті надаються можливі способи удосконалення чинного законодавства у сфері запобігання легалізації доходів, одержаних у злочинний спосіб.

Виклад основного матеріалу. Учені та практики констатують, що легалізація доходів, одержаних у злочинний спосіб, сьогодні перетворилися в найприбутковіший вид незаконного підприємнищтва. У світі за даними експертів Міжнародного Валютного Фонду щорічний обсяг відмивання грошей становить близько 500 млрд доларів США. За даними ДФС, в Україні щороку 
обсяг відмивання грошей становить близько 4 млрд доларів США. В Україні ведеться інтенсивна боротьба з цими злочинами, зокрема це проявляється в низці нормативно-правових актів, які регулюють порядок вирішення цього питання: Конвенція Ради Європи «Про відмивання, пошук, арешт та конфіскацію доходів, одержаних злочинним шляхом та про фінансування тероризму», Закон України «Про запобігання та протидію легалізації (відмиванню) доходів, одержаних злочинним шляхом, фінансуванню тероризму та фінансуванню розповсюдження зброї масового знищення» від 14 жовтня 2014 року № 1702-VII, Закон Украӥни «Про організаційно-правові основи боротьби з організованою злочинністю» від 30 червня 1993 року № 3341-XII, закон України «Про банки і банківську діяльність» від 07 грудня 2000 року № 2121-III, Указ Президента України «Про заходи щодо легалізації фізичними особами доходів, з яких не сплачено податки» від 31 березня 2000 року №552/2000 р., розпорядження Кабінету Міністрів України «Про реалізацію Стратегії розвитку системи запобігання та протидії легалізації (відмиванню) доходів, одержаних злочинним шляхом, фінансуванню тероризму та фінансуванню розповсюдження зброї масового знищення на період до 2020 року» від 30 серпня 2017 року № 601-р. тощо.

У Законі України «Про запобігання та протидію легалізації (відмиванню) доходів, одержаних злочинним шляхом, фінансуванню тероризму та фінансуванню розповсюдження зброї масового знищення» зазначається, що доходи, одержані злочинним шляхом, - будь-яка вигода, одержана внаслідок учинення суспільно небезпечного діяння, що передує легалізації (відмиванню) доходів, яка може складатися з рухомого чи нерухомого майна, майнових та немайнових прав, незалежно від їх вартості [8].

Легалізація злочинних доходів - це приховування їх існування, незаконного походження та використання без ідентифікації доходів, одержаних незаконно.

Учені спосіб учинення легалізації (відмиванням) доходів, одержаних у злочинний спосіб, розуміють насамперед, як:

- механізм надання правомірності злочинно здобутим прибуткам та надприбуткам (О. О. Дудоров);

- виведення «брудних» коштів зі сфери обігу тіньового капіталу 3 наданням видимості їх законного походження (Г. А. Матусовський);

- неконтрольоване введення в комерційний обіг грошових коштів (або майна) за допомогою легальних господарських структур на території України, відкриття дочірніх підприємств закордонних фірм, створення підприємницької оболонки, бачення високої рентабельності для приховання здійснюваних операцій (В. Ю. Шепітько);

- невід'ємну складову технологій злочинного збагачення, тобто комплексів взаємопов' язаних злочинних дій, що поєднані в єдиний ланцюг злочинної поведінки, де, власне, легалізація є останньою ланкою [7].

Пропонуємо дослідити об'єктивну сторону ч. 1 ст. 209 Кримінального кодексу України. Об'єктивна сторона складу злочину характеризується як сукупність ознак, які визначають зовнішню сторону злочину й характеризують суспільно-небезпечне діяння (дію або бездіяльність), його 
шкідливі наслідки та причинно-наслідковий зв'язок між діянням та наслідками, а також місце, час, обстановку, спосіб, стан, знаряддя та засоби вчинення злочину.

Диспозиція ч. 1 ст. 209 Кримінального кодексу України містить ряд альтернативних діянь, які можуть становити об'єктивну сторону цього злочину, зокрема: 1) учинення фінансової операції чи правочину з коштами або іншим майном, одержаними внаслідок учинення суспільно небезпечного протиправного діяння, що передувало легалізації (відмиванню) доходів; 2) учинення дій, спрямованих на приховування чи маскування незаконного походження таких коштів або іншого майна чи володіння ними, прав на такі кошти або майно, джерела їх походження, місцезнаходження, переміщення; 3) набуття, володіння або використання коштів чи іншого майна, одержаних унаслідок учинення суспільно небезпечного протиправного діяння, що передувало легалізації (відмиванню) доходів.

Учинення фінансової операції 3 коштами, одержаними внаслідок учинення суспільно-небезпечного діяння - учинення будь-якої фінансової операції, пов'язаної зі здійсненням або забезпеченням здійснення платежу за допомогою суб'єкта первинного фінансового моніторингу. У п. 47 ст. 1 Закону України «Про запобігання та протидію легалізації (відмиванню) доходів, одержаних злочинним шляхом, фінансуванню тероризму та фінансуванню розповсюдження зброї масового знищення» від 14 жовтня 2014 року зазначається, що фінансова операція - будь-які дії щодо активів клієнта, учинені за допомогою суб'єкта первинного фінансового моніторингу, або про які стало відомо суб'єктові державного фінансового моніторингу в рамках виконання цього Закону. Крім цього, Пленум ВСУ вказуе, що для максимального охоплення всіх видів фінансових операцій потрібно залежно від їх змісту звертатися також до нормативно-правових актів, що регламентують правовідносини в цій сфері.

Учинення правочину 3 коштами або іншим майном, одержаними внаслідок вчинення предикатного діяння - це вчинення з ними будь-якої дії, спрямованої на набуття, зміну або припинення цивільних прав та обов' язків. Цей правочин має здійснюватися в порядку, визначеному Цивільним кодексом України.

Щодо дій, спрямованих на приховування чи маскування незаконного походження коштів, одержаних у злочинний спосіб, то згідно 3 п. 8 Постанови Пленуму ВСУ від 15 квітня 2005 року № 5 під такими діями треба розуміти будь-які дії особи, за допомогою яких маскується чи приховується факт одержання таких коштів або іншого майна, що передував легалізації (відмиванню) цих доходів, учинені як особою, що одержала ці кошти або майно в такий спосіб, так і будь-якою іншою особою. Такі дії можуть бути спрямовані на: зміну правового статусу коштів або іншого майна способом підроблення документів, що засвідчують право власності; отримання фіктивних документів на придбання майна; учинення цивільно-правових угод (удавана купівля в комісійному магазині, ломбарді тощо); оформлення права власності на підставних осіб тощо. 
Під набуттям та володінням коштів чи іншого майна, одержаних унаслідок учинення суспільно небезпечного протиправного діяння, що передувало легалізації доходів потрібно розуміти набуття собою права власності на такі кошти чи майно при усвідомленні нею, що вони одержані іншими особами в злочинний спосіб, тобто особа знає про справжнє джерело цих доходів, але все одно їх набуває.

Під використанням коштів або іншого майна, одержаних унаслідок учинення предикатного діяння, треба розуміти їх використання в процесі легальних виробництва продукції, виконання робіт, надання послуг, торгівлі суб'єктами господарювання (підприємництва), зареєстрованими як такі в установленому законом порядку, а саме: 1) будь-яке інвестування зазначених коштів або іншого майна у господарську діяльність (внесення їх до статутного фонду такого суб'єкта або безоплатна передача йому, інвестування в спільну господарську діяльність тощо); 2) придбання за такі кошти сировини, продукції, іншого майна для використання в господарській діяльності; 3) використання такого майна як напівфабрикатів, сировини тощо (п. 9 Постанови Пленуму ВСУ від 15 квітня 2005 року № 5) [9].

Досі актуальним є питання щодо змісту предикатного діяння, передбаченого п. 1 примітки до ст. 209 КК Украйни, та погодження його 3 положеннями ст. 1 Конвенції Ради Європи про відмивання, пошук, арешт та конфіскацію доходів, одержаних у злочинний спосіб, та про фінансування тероризму від 16 травня 2005 року.

Відповідно до п. 1 примітки цієї статті предикатними діяннями можуть бути такі: 1) діяння, за яке Кримінальним кодексом України передбачено основне покарання у вигляді позбавлення волі або штрафу понад три тисячі неоподатковуваних мінімумів доходів громадян; 2) діяння, учинене за межами України, якщо воно визнається суспільно небезпечним протиправним діянням, що передувало легалізації (відмиванню) доходів, за кримінальним законом держави, де воно було вчинене, і є злочином за Кримінальним кодексом України та внаслідок учинення якого незаконно одержані доходи.

О. О. Чаричанський обгрунтовує свою позицію, що наявність обвинувального вироку суду по предикатному злочину для кваліфікації діяння за ст. 209 КК не є обов'язковою. Якщо уявити, що обвинувальний вирок суду тут потрібен, то його винесення мало б передувати застосуванню ст. 38 КK (затримання особи, яка вчинила злочин), статті 44-48 КК (звільнення від кримінальної відповідальності особи, яка вчинила злочин), ст. 198 КК (придбання або збут майна, завідомо здобутого злочинним шляхом) тощо. Крім цього, можливі ситуації, коли суб'єкт, що вчинив предикатний злочин, за певних причин не може бути притягнутий до кримінальної відповідальності (переховується від слідства, помер тощо), а одержані таким суб'єктом кошти легалізуються іншими особами. Відмічається, що аналогічну ситуацію підтверджує практика застосування ст. 198 КК - злочину, для кваліфікації якого достатньо лише усвідомлення особою злочинного характеру походження майна, до того ж точна 
обізнаність про характер та конкретні обставини вчиненого первинного злочину не вимагається [10].

У п. «е» ст. 1 Конвенції Ради Свропи про відмивання, пошук, арешт та конфіскацію доходів, одержаних у злочинний спосіб, та про фінансування тероризму зазначено, що «предикатний злочин» означає будь-який кримінальний злочин, у результаті якого виникли доходи, що можуть стати предметом злочину, зазначеного в статті 9 цієї Конвенції [4]. Тобто бачимо невідповідність п. 1 примітки ст. 209 Кримінального кодексу України зазначеній Конвенції. Хоча цікавим є факт, що ця Конвенція набрала чинності для України 2011 року, проте незважаючи на те, що 3 цього часу вже були зміни до Кримінального кодексу, але він і досі не відповідає п. «е» ст. 1 Конвенції Ради Свропи [5, с. 67].

Ще одним важливим питанням є зазначення в пункті 17 Постанови Пленуму ВСУ від 2005 року № 5 мети цього злочину, а саме: «згідно зі ст. 209 КК метою вчинення дій із коштами або іншим майном є надання їх походженню легального статусу». Проаналізувавши ч. 1 ст. 209 Кримінального кодексу України, можемо побачити, що мета не є обов'язковою ознакою цього складу злочину, оскільки безпосередньо там не зазначена. Проблема полягає в тому, що суди України не кваліфікують скоєне діяння за ст. 209 Кримінального кодексу, надаючи пріоритет положенням пункту 17 Постанови Пленуму ВСУ від 2005 року № 5, а не чинному Кримінальному кодексу України. Відповідно ч. 1-3 ст. 3 КК України: «1. Законодавство України про кримінальну відповідальність становить Кримінальний кодекс України, який грунтується на Конституції України та загальновизнаних принципах i нормах міжнародного права. 2. Закони України про кримінальну відповідальність, прийняті після набрання чинності цим Кодексом, включаються до нього після набрання ними чинності. 3. Злочинність діяння, а також його караність та інші кримінально-правові наслідки визначаються тільки цим Кодексом». Тому при виникненні суперечностей між положеннями постанов Пленуму ВСУ та Кримінальним кодексом України перевага надається останньому [9].

Висновки. Отже, дослідивши це питання, спираючись на праці науковців, можна дійти певних висновків. Розглядаючи п. 1 примітки ст. 209 Кримінального кодексу України та ст. 1 Конвенції Ради Європи про відмивання, пошук, арешт та конфіскацію доходів, одержаних у злочинний спосіб, та про фінансування тероризму бачимо їх суперечність. Предикатні діяння, зазначені в п. 1 примітки ст. 209 Кримінального кодексу України не відповідають п. «е» ст. 1 указаної Конвенції Ради Свропи. 3 огляду на це пропонуємо переглянути п. 1 примітки ст. 209 Кримінального кодексу України та узгодити з положеннями цієї Конвенції й викласти в такій редакції: «Суспільно небезпечним протиправним діянням, що передувало легалізації (відмиванню) доходів, відповідно до цієї статті є будь-який злочин, передбачений Кримінальним кодексом України, або діяння, учинене за межами України, якщо воно визнається суспільно небезпечним протиправним діянням, що передувало легалізації (відмиванню) доходів, за 
кримінальним законом держави, де воно було вчинене, i $є$ злочином за Кримінальним кодексом України та внаслідок учинення якого незаконно одержані доходи». Щодо мети цього злочину, то вона є факультативною ознакою суб' єктивної сторони, оскільки безпосередньо в диспозиції статті не зазначена, а отже, при кваліфікації діяння особи ії встановлення не є обов'язковим попри роз'яснення, закріплені в п. 17 Постанови Пленуму Верховного Суду України «Про практику застосування судами законодавства про кримінальну відповідальність за легалізацію (відмивання) доходів, одержаних злочинним шляхом» від 15 квітня 2005 року № 5.

\section{Використані джерела:}

1. Бандурка А. М., Симовьян С. В. Украина против «грязных» денег. Харків, ХНУВС, 2003. 35-45 c.

2. Журавель В. А. Розслідування легалізації (відмивання) доходів, одержаних злочинним шляхом. Настільна книга слідчого: наук.- практ. видання для слідчих і дізнавачів / [М. І. Панов, В. Ю. Шепітько, В. О. Коновалова та ін.]. 2ге вид., перероб. і доп. Київ : Вид. дім «Ін Юре», 2008. 322-335 с.

3. Кернер X.-X. Отмывание денег: Путеводитель по действующему законодательству и юридической практике / X.-Х. Кернер, 3. Дах; предисл. А. Э. Жалинского; пер. с нем. Т. Родионовой, Дж. Войновой. Москва : Международные отношения, $1996.40 \mathrm{c}$.

4. Конвенція Ради Європи про відмивання, пошук, арешт та конфіскацію доходів, одержаних злочинним шляхом, та про фінансування тероризму: Конвенція від 01 червня 2011 року / Рада Європи. URL: https://zakon.rada.gov.ua/laws/show/994_948 (дата звернення: 02.03.2019).

5. Крайник Г. С. Проблеми правової регламентації кримінальної відповідальності за легалізацію (відмивання) доходів, отриманих злочинним шляхом в Україні. "Сучасні проблеми фінансового моніторингу»: матеріали VI Всеукраїнської науково-практичної конференції (Харків, 23 листопада 2018 року). Харків: ХНЕУ імені Семена Кузнеця, 2018. С. 66-68.

6. Кримінальний кодекс України: Кодекс України від 05 квітня 2001 року № 2341-III / Верховна Рада України. URL: https://zakon.rada.gov.ua (дата звернення: 02.03.2019).

7. Ортинський В. Л. Характеристика легалізації (відмивання) доходів, одержаних злочинним шляхом: криміналістичні аспекти. URL: http://ena.lp.edu.ua/bitstream/ntb/37453/1/79_533 (дата звернення: 02.03.2019).

8. Про запобігання та протидію легалізації (відмиванню) доходів, одержаних злочинним шляхом, фінансуванню тероризму та фінансуванню розповсюдження зброї масового знищення : Закон України від 14 жовтня 2014 року № 1702-VII / Верховна Рада України. URL: https:/ /zakon.rada.gov.ua/laws/show/1702-18 (дата звернення: 02.03.2019).

9. Про практику застосування судами законодавства про кримінальну відповідальність за легалізацію (відмивання) доходів, одержаних злочинним шляхом : Постанова Пленуму Верховного Суду України від 15 квітня 2005 року № 5 / Верховний Суд України. Вісник Верховного Суду України. 2005 р. № 5 Ст. 9.

10. Чаричанський О. О. Підстави кримінальної відповідальності за легалізацію (відмивання) доходів, одержаних злочинним шляхом, за Кримінальним кодексом 
України: автореф. дис. на здобуття наук. ступеня канд. юрид. наук: 12.00.08. Харків, 2004. 22 c.

Стаття надійшла до редколегї 12.01.2019

Крайник Г. С., кандидат юридических наук, ассистент кафедры уголовного права № 1 Национального юридического университета имени Ярослава Мудрого (г. Харьков, Украина)

Заточна В. А., студентка 3 курса Института прокуратуры и уголовной юстиции Национального юридического университета имени Ярослава Мудрого (г. Харьков, Украина)

Вопросы уголовной ответственности за легализацию (отмывание) доходов, полученных преступным путем

В данной статье освещены объективная сторона состава преступления, предусмотренного ч. 1 ст. 209 Уголовного кодекса Украины, а также п. 1 примечания к ст. 209 Уголовного кодекса. Рассмотрено законодательное регулирование противодействия легализации доходов, полученных преступным путем, предложено внести изменения в законодательство Украины в этой сфере. Уделено внимание несоответствия п. 1 примечания ст. 209 Уголовного кодекса Украины Конвенции Совета Европы об отмывании, поиске, аресте и конфискации доходов, полученных преступным путем, и о финансировании терроризма. Предложено внести изменения в п. 1 ст. 209 Уголовного кодекса. Также рассмотрено такой признак субъективной стороны данного преступления как цель. Выяснено, что это факультативный признак субъективной стороны, несмотря на объяснения Пленума Верховного Суда Украины.

Ключевые слова: доходы, полученные преступным путем, легализация (отмывание) доходов, противодействие отмыванию доходов, основное правонарушение, финансирование терроризма.

Krainyk H., Zatochna V. Problems of Criminal Responsibility for the Legalization (Washing) of Profits Received by the Criminal Way

This article covers the objective side of the crime, provided for in Part 1 of art. 209 of the Criminal Code of Ukraine. It is the commission of a financial transaction or transaction with funds or other property obtained as a result of the commission of a socially dangerous unlawful act preceding the legalization (laundering) of proceeds; the commission of actions aimed at concealing or disguising the illegal origin of such funds or other property or ownership thereof, rights to such funds or property, sources of their origin, location, and movement; the acquisition, possession or use of funds or other property obtained as a result of the commission of a socially dangerous unlawful act preceding the legalization (laundering) of the proceeds.

Paragraph 1 of art. 209 of the Criminal Code of Ukraine is also considered. Legislative regulation of counteraction to the legalization of proceeds from crime is considered. It is suggested that the legislation of Ukraine in this area be amended. Attention is paid to the non-compliance of Item 1 of the note of art. 209 of the Criminal Code of Ukraine of the Council of Europe Convention on Laundering, Search, Seizure and Confiscation of the Proceeds from Crime and on the Financing of Terrorism.

It is proposed to amend the clause 1 of the article 209 of the Criminal Code Also considered such a sign of the subjective aspect of the crime as a goal. It has been found 
out that this is an optional feature of the subjective party, despite the explanation of the Plenum of the Supreme Court of Ukraine.

Key words: proceeds from crime, legalization (laundering) of incomes, counteraction to money laundering, predicate crime, terrorist financing.

УДК 343.985 .3

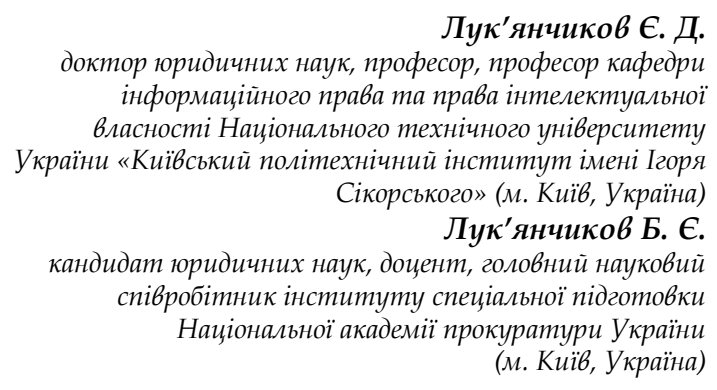

\section{ФОРМУВАННЯ ІНСТИТУТУ НЕГЛАСНИХ СЛІДЧИХ (РОЗШУКОВИХ) ДІЙ}

У статті проаналізовано нормативне регулювання інструментарію пізнавальної діяльності 3 розслідування кримінальних правопорушень. Розглянуто думки науковців щодо визначення слідчих дій і відмежування їх від інших процесуальних дій і засобів забезпечення кримінального провадження. Розкрито об'єктивні передумови закріплення в КПК України низки слідчих (розшукових) дій, відомості про факт та методи проведення яких не підлягають розголошенню.

Зроблено висновок про те, що запровадження інституту негласних слідчих (розшукових) дій $є$ закономірним результатом розвитку кримінального процесуального законодавства, головна мета якого полягає в забезпеченні прав та інтересів обох сторін кримінального провадження.

Ключові слова: злочин, засоби пізнавальної діяльності, слідчі (розшукові) дії, процесуальні дії, пошук, розшук, розшукова діяльність.

Постановка проблеми. Сучасний етап розвитку суспільства супроводжується суттєвими змінами в економіці, політищі, розвитку міжнародних відносин. Негативного впливу на ці процеси завдає злочинність, яка характеризується не тільки кількісними, а здебільшого якісними змінами. 3'являються нові види злочинів (у сфері високих технологій, розкрадання в бюджетній та фінансово-кредитній сферах), зростає корисливо-насильницька злочинність, дії злочинців стають усе більш жорстокими та зухвалими, підвищується професіоналізація, організованість і корумпованість злочинності, яка набуває транснаціонального характеру. На цьому тлі знижується, за різних обставин, активність законослухняних громадян у наданні правоохоронним органам інформації про злочини, яка стала їм відомою. 3 огляду на це зменшуються інформаційні можливості правоохоронних органів у своєчасному виявленні злочинів, встановленні всіх його обставин та осіб, причетних до цього. Суттєве зростання навантаження на правоохоронні органи та збільшення () Лук'янчиков С.Д.,

Лук'янчиков Б.С., 2019 